\title{
Community composition of bacterial biofilms on two submerged macrophytes and an artificial substrate in a pre-alpine lake
}

\author{
Melanie Hempel ${ }^{1, *}$, Hans-Peter Grossart ${ }^{2}$, Elisabeth M. Gross ${ }^{1}$ \\ ${ }^{1}$ Limnological Institute, Department of Biology, University of Konstanz, PO Box 659, 78457 Konstanz, Germany \\ ${ }^{2}$ Leibniz Institute of Freshwater Ecology and Inland Fisheries (IGB), Department of Limnology of Stratified Lakes, \\ Alte Fischerhuette 2, 16775 Stechlin, Germany
}

\begin{abstract}
We compared the heterotrophic community composition of bacterial biofilms on the submerged macrophytes Myriophyllum spicatum and Potamogeton perfoliatus and on an artificial surface in Lower Lake Constance (Germany) on spatial (plant age) and temporal scales using denaturing gradient gel electrophoresis (DGGE) and fluorescence in situ hybridization (FISH). M. spicatum contains polyphenolic allelochemicals that inhibit algae, cyanobacteria, and heterotrophic bacteria, and possibly influence the community composition, whereas P. perfoliatus does not. In 2005, the community composition of bacterial biofilms on apices and leaves of $M$. spicatum differed significantly. In 2006, the biofilm communities on the apices or leaves of $M$. spicatum and $P$. perfoliatus and the artificial surface did not differ significantly, although all except one apex sample of $M$. spicatum formed a distinct cluster based on DGGE banding patterns. On all surfaces, members of the CytophagaFlavobacter-Bacteroidetes (CFB) group (16 to 22\%), Alphaproteobacteria (19\%), and Betaproteobacteria ( 7 to $31 \%$ ) were abundant; Actinobacteria and Planctomycetes occurred less frequently. Sequences of DNA fragments excised from DGGE gels were mainly affiliated with yet uncultured clones originating from various freshwater habitats. Several sequences were from bacteria capable of degrading phenolic and aromatic compounds. The chemical composition of the 2 plant species and of the different parts of $M$. spicatum differed up to an order of magnitude. Differences in the biofilm community composition mainly depended on environmental factors (water level, conductivity, temperature, $\mathrm{pH}$ ) and the plant chemical composition, especially the carbon and total phenolic content. Our results suggest that the biofilm community on $M$. spicatum apices is related to specific bacterial functions in this microenvironment.
\end{abstract}

KEY WORDS: Myriophyllum spicatum $\cdot$ Potamogeton perfoliatus $\cdot$ DGGE $\cdot$ FISH $\cdot$ Phenolic compounds $\cdot$ Biofilms $\cdot$ Macrophytes

\section{INTRODUCTION}

Submerged macrophytes are the major primary producers in the littoral zones of lakes. They structure these zones by reducing sediment resuspension and providing spawning areas and shelter for young fishes and zooplankton. They further offer a vast surface area for the attachment of various organisms, from bacteria and algae to invertebrates (Jeppesen et al. 1998).
Heterotrophic bacteria largely contribute to the overall nutrient cycling and interact in various ways with other organisms by relocating nutrients, converting degradation products, restoring growth forms of macroalgae, facilitating spore attachment, and preventing grazing (Joint et al. 2000, Buesing \& Gessner 2006, Marshall et al. 2006). In the root sections of macrophytes, bacteria are generally recognized as important mediators of macrophyte nutrient uptake, especially 
nitrogen (Eriksson \& Weisner 1999). In return, macrophytes provide substrates for bacteria, e.g. exuded organic compounds or gases such as methane from the root zone; these substrates can be transported through the lacunar system, i.e. the aerenchyme that provides gas exchange between roots and shoots in aquatic higher plants, to the above-ground plant parts and released into the water column (Gross et al. 1996, Schuette 1996, Heilman \& Carlton 2001). Bacteria can also have negative effects on their hosts by invading and damaging tissue and promoting biofouling (Underwood 1991). Potential negative consequences, e.g. decreased exchange of nutrients and reduced photosynthesis, can also occur if excessive bacterial biofilms form (Phillips et al. 1978, Sand-Jensen \& Søndergaard 1981). The littoral zone is therefore not solely characterized by the macrophyte community but also by their autotrophic and heterotrophic biofilms.

Terrestrial plants display chemical defenses against competitors, pathogens, and herbivores. An aquatic dicotyledonous angiosperm with a high allelochemical potential in Lake Constance, Germany, is Myriophyllum spicatum L. It has canopy-forming growth and produces high amounts of hydrolyzable polyphenols that retard larval growth and inhibit photosynthesis and bacterial growth (Choi et al. 2002, Leu et al. 2002, Walenciak et al. 2002). These polyphenols are located in the plant tissue and may also leak from leaves into the surrounding water. Thus, biofilms on the surface of these plants are exposed to polyphenols in high concentrations, and the bacteria may develop specific adaptations, such as the utilization of polyphenols as substrates (Müller et al. 2007). Another macrophyte growing in the vicinity of $M$. spicatum in Lake Constance is the monocotyledonous pondweed Potamogeton perfoliatus, which forms large stands in water depths of 3 to $4 \mathrm{~m}$, with shoots reaching the water surface. It contains only very low amounts of phenolic compounds but no polyphenols (Choi et al. 2002). We do not know if $P$. perfoliatus also contains diterpenes, which have been found in several other pondweeds and inhibit microalgae (DellaGreca et al. 2001). Our long-term analyses show that the chemical composition of M. spicatum in Lake Constance varies seasonally and forms a gradient of macro- and micronutrients and phenolic compounds from the apices to the older leaves (E. Gross unpubl.; the present study). In contrast, P. perfoliatus generally forms no pronounced macronutrient gradients (E. Gross unpubl.; the present study).

Little attention has been paid to the heterotrophic bacterial biofilm on submerged freshwater macrophytes, and especially to the spatial differences in composition of the biofilms on younger and older leaves. Studies of heterotrophic bacteria in biofilms on macrophytes with cultivation-dependent techniques
(Chand et al. 1992) are often biased owing to the selectivity of the media used. In contrast, many of the molecular studies of the biofilm community on aquatic interfaces have been carried out using artificial surfaces (Olapade \& Leff 2006) or marine micro- and macroalgae (Grossart et al. 2005, Rao et al. 2006). Only recently, more information on epiphytic bacteria on freshwater macrophytes, among them pondweeds (Potamogeton perfoliatus), has become available (Crump \& Koch 2008, Hempel et al. 2008).

Here we investigated and compared the composition of the bacterial biofilm community on different macrophyte species, different parts of the same plant, and artificial surfaces in Lake Constance. We determined whether the chemical composition of the apices and the lower leaves of Myriophyllum spicatum differed and whether the bacterial community composition of the polyphenol-rich $M$. spicatum is distinct from that of the polyphenol-free Potamogeton perfoliatus or an artificial surface. We measured the contents of carbon, nitrogen, phosphorus, chlorophyll, total phenolic content, and anthocyanins in the 2 plants, and the hydrolyzable polyphenol tellimagrandin II in M. spicatum. In 2005, we investigated spatial differences in the biofilm community of younger and older plant parts of M. spicatum using denaturing gradient gel electrophoresis (DGGE). In summer 2006, we extended our study and compared the biofilm communities on $M$. spicatum, $P$. perfoliatus, and polypropylene sheets using DGGE, sequencing, and fluorescence in situ hybridization (FISH) for major bacterial groups.

\section{MATERIALS AND METHODS}

Sampling. All samples were collected near the Island of Reichenau in Lower Lake Constance, Germany ( $\left.47^{\circ} 42^{\prime} \mathrm{N}, 9^{\circ} 02^{\prime} \mathrm{E}\right)$. In July, August, and October 2005, we sampled 3 different plant stands of Myriophyllum spicatum during the growing season within an area of approximately $20 \mathrm{~m}^{2}$. In 2006, we sampled M. spicatum, Potamogeton perfoliatus, and an artificial surface (polypropylene sheets) every $2 \mathrm{wk}$ between 17 July and 9 October at a depth of 1.5 to $2.6 \mathrm{~m}$. The $0.3 \mathrm{~mm}$ thick polypropylene sheets (Ibico; $9.7 \times 1.2 \mathrm{~cm}$ ) were deployed at $2.6 \mathrm{~m}$ water depth $2 \mathrm{wk}$ before sampling began. A hole was punched into each end of each sheet. A float was tied to 1 end to ensure an upright position; a lace was tied to the other end and to a plastic bar fixed to the ground with tent pegs.

We sampled Myriophyllum spicatum, Potamogeton perfoliatus, and the artificial surfaces by snorkeling. Plants and artificial surface samples were stored individually in sterile $50 \mathrm{ml}$ polyethylene tubes at $4^{\circ} \mathrm{C}$ until processing $(<24 \mathrm{~h})$. We stored plants for chemical analyses 
in plastic bags at $4{ }^{\circ} \mathrm{C}$ until analysis the next day. On each sampling date, 3 replicates consisting of at least 5 plants from 1 stand were analyzed, and temperature, oxygen, conductivity, and $\mathrm{pH}$ were measured in the water column $20 \mathrm{~cm}$ below the water surface.

Detachment of epiphytic biofilm. In the laboratory, we measured plant length and recorded the overall state of the plant by observing the color of the leaves and the approximate leaf damage caused by grazing. Artificial surfaces were documented photographically. The plant was divided into 3 sections: the apex, the mid-shoot ( 1 to $10 \mathrm{~cm}$ from the apex), and the lower shoot (10 to $25 \mathrm{~cm}$ from the apex). We defined the apex as the growing tip of the main shoot. The apices were separated from the main shoot at the node below which the internode length exceeded $5 \mathrm{~mm}$. From this apical section, we used 1 differentiated leaf for the measurements. For FISH analyses, 9 leaves were sampled in total, 1 from each section of 3 plants located in 3 different stands. Each leaf and also a section of each artificial surface $\left(\sim 1 \mathrm{~cm}^{2}\right)$ were transferred to $1 \mathrm{ml}$ $0.1 \mathrm{M} \mathrm{Na}_{4} \mathrm{P}_{2} \mathrm{O}_{7} \times 10 \quad \mathrm{H}_{2} \mathrm{O}$ containing $3.7 \%$ formaldehyde. The biofilm was detached by $1 \mathrm{~min}$ of ultrasonication (Laboson 200 ultrasonic bath, Bender \& Hobein), 15 min of shaking $(18.3 \mathrm{~Hz}$, horizontal shaker, Eppendorf), and subsequent ultrasonication for $1 \mathrm{~min}$. We recently optimized the detachment of epiphytic bacteria from macrophytes (Hempel et al. 2008). After detachment of the biofilm, leaves were transferred into $1 \mathrm{ml}$ of tap water and stored at $4^{\circ} \mathrm{C}$ until the leaf surface area was measured. The detached biofilm was filtered onto white polycarbonate filters $(0.2 \mu \mathrm{m}$; $\Delta 25 \mathrm{~mm}$, Schleicher \& Schuell) and stored at $-20^{\circ} \mathrm{C}$.

For bacterial DNA isolation, we transferred 1 apex, 5 (Potamogeton perfoliatus) or 13 (Myriophyllum spicatum) lower leaf sections, and $2 \mathrm{~cm}$ of the middle part of 1 artificial surface to $15 \mathrm{ml} 0.1 \mathrm{M} \mathrm{Na}_{4} \mathrm{P}_{2} \mathrm{O}_{7} \times 10 \mathrm{H}_{2} \mathrm{O}$. Fewer leaves of $P$. perfoliatus were sampled because the leaf surface was much larger $\left(6.5 \pm 2.8 \mathrm{~cm}^{2}\right.$, mean \pm $1 \mathrm{SD})$ than that of $M$. spicatum $\left(1.7 \pm 0.6 \mathrm{~cm}^{2}\right)$. Since precise standardization of the sampled leaf area would have been too time consuming, we considered each unit to equal 1 leaf per plant section. The biofilm on each sample was detached as described above. The suspension containing the detached biofilm was filtered onto ME 24 membrane filters $(0.2 \mu \mathrm{m} ; \Delta 45 \mathrm{~mm}$, Schleicher \& Schuell) and stored at $-20^{\circ} \mathrm{C}$ until the DNA was extracted.

FISH. FISH was performed following a protocol including hybridization at $46^{\circ} \mathrm{C}$ for $3 \mathrm{~h}$ and washing for $15 \mathrm{~min}$ at $48^{\circ} \mathrm{C}$ (Pernthaler et al. 2001). Filters were counterstained with 4',6-diamidino-2-phenylindole (DAPI, $1 \mu \mathrm{g} \mathrm{ml}{ }^{-1}, 5 \mathrm{~min}$ ). At least 300 DAPI-stained cells or $3 \times 100$ fields of vision were counted under an epifluorescence microscope (Labophot 2, Nikon) with excitation at $549 \mathrm{~nm}$ and with $1000 \times$ magnification. The probes used are listed in Table 1, and further details are available at probeBase (Loy et al. 2003).

Measurement of leaf surface. To relate total cell counts to the surface area of the plants, we photographed the leaves with a Nikon D70S and analyzed the pictures with Makrophyt, a computer program designed by the scientific workshops of the University of Konstanz. The software calculates the leaf area based on the number of black and white grid cells found on a given photograph. The area of the outer edge of the leaf was calculated and then adjusted visually to account for detached leaf filaments. Each leaf was photographed with 3 different exposure times, and the mean leaf size was calculated. The calculated area of Myriophyllum spicatum was multiplied by $\pi$ to account for the circular shape of the leaves. To calculate the leaf surface of Potamogeton perfoliatus, the area was multiplied by 2 since the oval leaves are laminar.

DNA extraction. The ME 24 membrane filters detailed in 'Detachment of epiphytic biofilm' were cut into small pieces, and DNA was extracted following a standard phenol/chloroform protocol with an additional lysozyme step (8 $\mathrm{mg} \mathrm{ml}^{-1} ; 260 \mu \mathrm{l} \mathrm{sample}{ }^{-1}$; $30 \mathrm{~min}$ at $65^{\circ} \mathrm{C}_{i}$ Walenciak 2004). Extracted DNA was dried, re-dissolved in $40 \mu \mathrm{l}$ of DNA-free water, and quantified photometrically at $260 \mathrm{~nm}$.

Polymerase chain reaction (PCR). PCR was performed in a Thermocycler T-Gradient (Biometra). We

Table 1. Oligonucleotide probes used in this study. Probes were labeled with cy3

\begin{tabular}{|llcll|}
\hline Probe & Sequence & \% Formamide & Target group & Source \\
\hline EUB338 & GCTGCCTCCCGTAGGAGT & 35 & Most bacteria & Amann et al. (1990) \\
NON338 & ACTCCTACGGGAGGCAGC & 35 & Competitor of EUB & Wallner et al. (1993) \\
ALF968 & GGTAAGGTCTGCGCGT & 20 & Alphaproteobacteria & Neef (1997) \\
BET42a ${ }^{a}$ & GCCTTCCCACTTCGTTT & 35 & Betaproteobacteria & Manz et al. (1996) \\
GAM42a $\mathrm{a}^{\mathrm{a}}$ & GCCTTCCCACATCGTTT & 35 & Gammaproteobacteria & Manz et al. (1992) \\
PLA886 & GCCTTGCGACCATACTCCC & 35 & Planctomycetes & Neef et al. (1998) \\
HGC96a & TATAGTTACCACCGCCGT & 25 & Actinomycetes & Roller et al. (1994) \\
CF319a & TGGTCCGTGTCTCAGTAC & 35 & Bacteroidetes & Manz et al. (1996) \\
aFor these probes, a competitor probe was used & & & \\
\hline
\end{tabular}


used the primers 341f $\left(5^{\prime}-\mathrm{CCT}\right.$ ACG GGA GGC AGC AG-3'; Muyzer et al. 1993) and 907r (5'-CCG TCA ATT CMT TTG AGT TT-3'; Lane et al. 1985). For DGGE, primer $341 \mathrm{f}$ was supplemented with a GC clamp (5'-CGC CCG CCG CGC CCC GCG CCC GTC CCG CCG CCC CCG CCC-3'; Muyzer et al. 1995). One $50 \mu \mathrm{l}$ PCR reaction contained $5 \mu \mathrm{l} 10 \times$ Taq buffer (Eppendorf), $5 \mu \mathrm{l} 500 \mathrm{mM}$ dNTP mix (Eppendorf), $0.5 \mu \mathrm{l}$ of forward primer at $25 \mathrm{pmol} \mathrm{\mu l}^{-1}, 0.5 \mu \mathrm{l}$ of reverse primer at $25 \mathrm{pmol} \mathrm{pl}^{-1}, 3 \mu \mathrm{Ll} 25 \mathrm{mM} \mathrm{MgCl}_{2}$ (Eppendorf), $10 \mu \mathrm{l} 6 \mathrm{mg} \mathrm{ml}^{-1}$ BSA (Sigma), and $0.2 \mu \mathrm{l}$ (1 U) Taq polymerase (Eppendorf). The following protocol was used for amplification: $5 \mathrm{~min}$ at $95^{\circ} \mathrm{C}$; followed by 30 cycles of $1 \mathrm{~min} 95^{\circ} \mathrm{C}, 1 \mathrm{~min}$ at $55^{\circ} \mathrm{C}$, and 2 min at $72^{\circ} \mathrm{C}_{i}$ ending with $15 \mathrm{~min}$ at $72^{\circ} \mathrm{C}$. PCR fragment lengths were quantified by gel electrophoresis using standards (Mass Ruler ${ }^{\mathrm{TM}}$ DNA Ladder Mix, Fermentas). We did not retrieve PCR products from all replicates, probably because of the high polyphenol content in M. spicatum plants, which resulted in variable replicate numbers. Thus, the original sample number is not always identical to the analyzed sample number.

DGGE. We performed DGGE in an INGENY PhorU system. For better comparison of DGGE banding patterns, equal amounts of PCR products ( $50 \mathrm{ng}$ ) were loaded onto the gel, and an external standard was used. DGGE was performed in a $7 \%(\mathrm{v} / \mathrm{v})$ polyacrylamide gel with a denaturing gradient of 40 to $70 \%$ urea and formamide, and was run at $60^{\circ} \mathrm{C}$ for $20 \mathrm{~h}$. Gels were stained with $1 \times$ SybrGold (Invitrogen), washed in deionized water, and documented with an AlphaImager 2200 Transilluminator (Biozym) under UV light. Bands were excised from the gel with a sterile scalpel and immediately transferred to a sterile PCR cup, in which DNA was eluted with sterile water. DNA was amplified using the primer pair 341f/907r (without a GC clamp) and conditions as described in 'Polymerase chain reaction'. DNA was sequenced at 4 base lab (Reutlingen). DGGE gels were analyzed with the software GelCompar II version 3.5 (Applied Maths). Cluster analysis was performed with Pearson's correlation using the unweighted pair group method with arithmetic mean (UPGMA).

Chemical analyses. We analyzed different plant parts spectrophotometrically for total phenolic content (Folin-Ciocalteau assay; Box 1983); anthocyanin (Murray \& Hackett 1991); carbon, nitrogen, and phosphorus (Choi et al. 2002); chlorophyll (chl) $a$ and $b$ (Porra 1990); and, only in Myriophyllum spicatum, for tellimagrandin II by HPLC (Müller et al. 2007). In contrast to $M$. spicatum, only about $50 \%$ of the Folin-sensitive compounds in Potamogeton perfoliatus are phenolic compounds (Choi et al. 2002); thus, for the latter species, the results of the Folin-Ciocalteau assay were halved to reflect the true total phenolic content. As a part of our routine sampling, $3 \mathrm{M}$. spicatum replicates originating from 3 different stands were measured. We measured $P$. perfoliatus plants originating from 1 stand, and thus only 1 measurement for each sampling date is available. Our long-term data set shows that plants originating from 1 location usually do not differ substantially in chemical composition (E. Gross unpubl. data; see also Choi et al. 2002).

Statistics. To analyze significant differences and potential interactions between the biofilm community compositions on the surfaces at different times, we used 1-way analysis of variance (ANOVA) to compare differences among all 3 surfaces or between individual sampling dates. Mann-Whitney rank sum tests were used to distinguish differences between parts of both plants, and Pearson correlations were used to investigate continuous seasonal changes for FISH-derived data (Sigma Stat 3.11, Systat Software). The proportional FISH data were arcsine transformed, and data for Gammaproteobacteria, Planctomycetes, Actinomycetes, and the Cytophaga-Flavobacter-Bacteroidetes $(C F B)$ group were additionally $x^{1 / 4}$ transformed to yield equal variance. To account for the multiple comparisons, we set our level of significance at $\alpha=0.01$.

We related both the FISH abundance and DGGE data separately to plant chemical composition and environmental conditions with a BEST-ENV analysis to see which factors best explain the differences between the 2 plant species. A dissimilarity matrix was calculated based on Bray-Curtis dissimilarity for square-root-transformed FISH data or a presence/ absence matrix calculated for the DGGE data. A dissimilarity matrix was calculated for standardized environmental data with Euclidean distance. For the plant chemical composition, we chose tissue nitrogen, carbon, phosphorus, chlorophyll, and total phenolic content, and as environmental factors, we chose water level, temperature, conductivity, and $\mathrm{pH}$. The data were normalized to allow a comparison between different units. This means that all data are placed on a common scale by subtracting the mean of each variable from each value and dividing the product by the standard deviation. This yields values in the range of -2 to +2 . The ranks of both matrices were compared by Spearman rank coefficient $(\rho)$ to find the best match between them. To provide statistical validation, 999 permutations were carried out.

Furthermore, the DGGE data transformed to a presence/absence matrix were subjected to a non-metric dimensional scaling (NMDS) analysis, which places the data in relation to each other based on the similarities between the samples. Samples that are more alike will be close together, while samples with more dissimilarity will be separated. These analyses were per- 
formed with Primer 6 (Version 6.1.6, Primer E). Analysis of similarity (ANOSIM) for the biofilm community composition was performed with Primer 6 to estimate the similarity between different plant parts of Myriophyllum spicatum in 2005 and among surfaces in 2006. To indicate the degree of separation between groups, ANOSIM generates a test statistic (R).

\section{RESULTS}

\section{Environmental variables and plant condition}

Environmental conditions changed during the sampling period in 2006 from July to October (Table 2). The temperature decreased from the beginning $\left(25.5^{\circ} \mathrm{C}\right)$ to the end of the study period $\left(15.6^{\circ} \mathrm{C}\right)$ by about $10^{\circ} \mathrm{C}$. The water level on the sampling dates was more or less constant around $319 \mathrm{~cm}$, with the maximum $25 \mathrm{~cm}$ higher and the minimum $27 \mathrm{~cm}$ lower. Conductivity and $\mathrm{pH}$ were also relatively constant $\left(267 \pm 14 \mu \mathrm{S} \mathrm{cm}{ }^{-1}\right.$ and $8.3 \pm 0.2$, mean $\pm \mathrm{SD}$, respectively).

Throughout the sampling period in 2006, Myriophyllum spicatum shoots were 30 to $45 \mathrm{~cm}$ long, with dark green leaves and typical red stems, and were covered with a thin, only microscopically visible layer of epiphytic algae and cyanobacteria. M. spicatum lower leaves had more epiphytes, made visible by the brown diatoms. Potamogeton perfoliatus shoots were 20 to $50 \mathrm{~cm}$ long and had intact, bright green leaves during summer. The leaves had a calcareous layer on the upper surface, and both sides were covered with thin layers of epiphytes. Neither plant species showed severe signs of grazing. M. spicatum did not show any sign of senescence throughout the sampling period, whereas the entire leaf area of $P$. perfoliatus turned brown at the end of September and in October because of senescence. The physiological state of the leaves was quantified by measuring their chlorophyll content

Table 2. Environmental variables measured on sampling dates in 2006. Water level was measured by the water gauge at Konstanz Harbor

\begin{tabular}{|lccccc|}
\hline $\begin{array}{l}\text { Sampling } \\
\text { date }\end{array}$ & $\begin{array}{c}\text { No. sampling } \\
\text { date }\end{array}$ & $\begin{array}{c}\text { Temperature } \\
\left({ }^{\circ} \mathrm{C}\right)\end{array}$ & $\begin{array}{c}\text { Water level } \\
(\mathrm{cm})\end{array}$ & $\begin{array}{c}\text { Conductivity } \\
\left(\mu \mathrm{S} \mathrm{cm}^{-1}\right)\end{array}$ & $\mathrm{pH}$ \\
\hline 17 July & 1 & 25.5 & 331 & 251 & 8.30 \\
31 July & 2 & 25.6 & 310 & 248 & 8.61 \\
15 August & 3 & 18.7 & 324 & 265 & 8.53 \\
29 August & 4 & 17.6 & 321 & 263 & 8.27 \\
12 September & 5 & 20.0 & 324 & 263 & 8.06 \\
22 September & 6 & 18.9 & 329 & 274 & 8.41 \\
9 October & 7 & 16.2 & 322 & 286 & 8.01 \\
23 October & 8 & 15.6 & 292 & 282 & 8.23 \\
\hline
\end{tabular}

(see next section). At the beginning of the sampling period, the artificial surfaces were covered with a thin layer of bacteria and algae; with increasing exposure time, the artificial surfaces were covered with up to several layers of the zebra mussel Dreissena polymorpha.

\section{Chemical analyses}

Plant C/N/P stoichiometry 2006

The molar $\mathrm{C} / \mathrm{N}$ ratio in Myriophyllum spicatum ranged between $13 \pm 2$ and $32 \pm 2$ and was highly variable during the season and among the different plant parts. The $\mathrm{C} / \mathrm{N}$ ratio formed a gradient from the apices (lowest) to the lower leaves (highest), and it declined over the sampling period, from late summer to autumn (Fig. 1A). The seasonal change was caused by an increase in the nitrogen content of the plants (in $\mathrm{mg}$ [g dry mass] ${ }^{-1}$ : apices, 19 to 44 ; middle leaves, 12 to 36; lower leaves, 7 to 25) and differences in the carbon content (in mg [g dry mass] ${ }^{-1}$ : apices, 403 to 455 ; middle leaves, 289 to 437; lower leaves, 201 to 350). The molar $\mathrm{C} / \mathrm{N}$ ratio in Potamogeton perfoliatus ranged from 10 to 27, and was more constant throughout the season in leaves than in apices (Fig. 1B).

The phosphorus content in Myriophyllum spicatum was highest in the apices (1.8 to $3.5 \mathrm{mg}$ [g dry mass] ${ }^{-1}$ ) and increased in autumn. The phosphorus content also increased in the middle and lower leaves in autumn, and the content was slightly higher in lower leaves $\left(0.8 \pm 0.3 \mathrm{mg}[\mathrm{g} \text { dry mass }]^{-1}\right.$, mean $\left.\pm \mathrm{SD}\right)$ than in middle leaves $(0.5 \pm 0.2 \mathrm{mg} \text { [g dry mass }]^{-1}$; Fig. $\left.1 \mathrm{C}\right)$. The phosphorus contents of the apices and leaves of Potamogeton perfoliatus were similar ( 0.5 to $1.2 \mathrm{mg}$ [g dry mass $]^{-1}$ ), with higher values in mid-September and at the end of October in all plant parts (Fig. 1D).

The chlorophyll content of Potamogeton perfoliatus was slightly higher than that of Myriophyllum spicatum (Fig. 1E,F), with a strong decrease from the beginning of September until the end of the sampling period. The apices $(6 \pm 2 \mathrm{mg}$ [ $\mathrm{g}$ dry mass $^{-1}$ ]) of $P$. perfoliatus always contained less chlorophyll than the middle and lower leaves $(7 \pm 2$ and $9 \pm$ $3 \mathrm{mg}$ [g dry mass $^{-1}$ ], respectively). The chlorophyll content in $M$. spicatum increased in all plant parts over the sampling period, and was higher in apices and middle leaves than in lower leaves $(5 \pm 1,6 \pm 2$, and $4 \pm$ $2 \mathrm{mg}$ [g dry $\mathrm{mass}^{-1}$ ], respectively; Fig. 1E). 

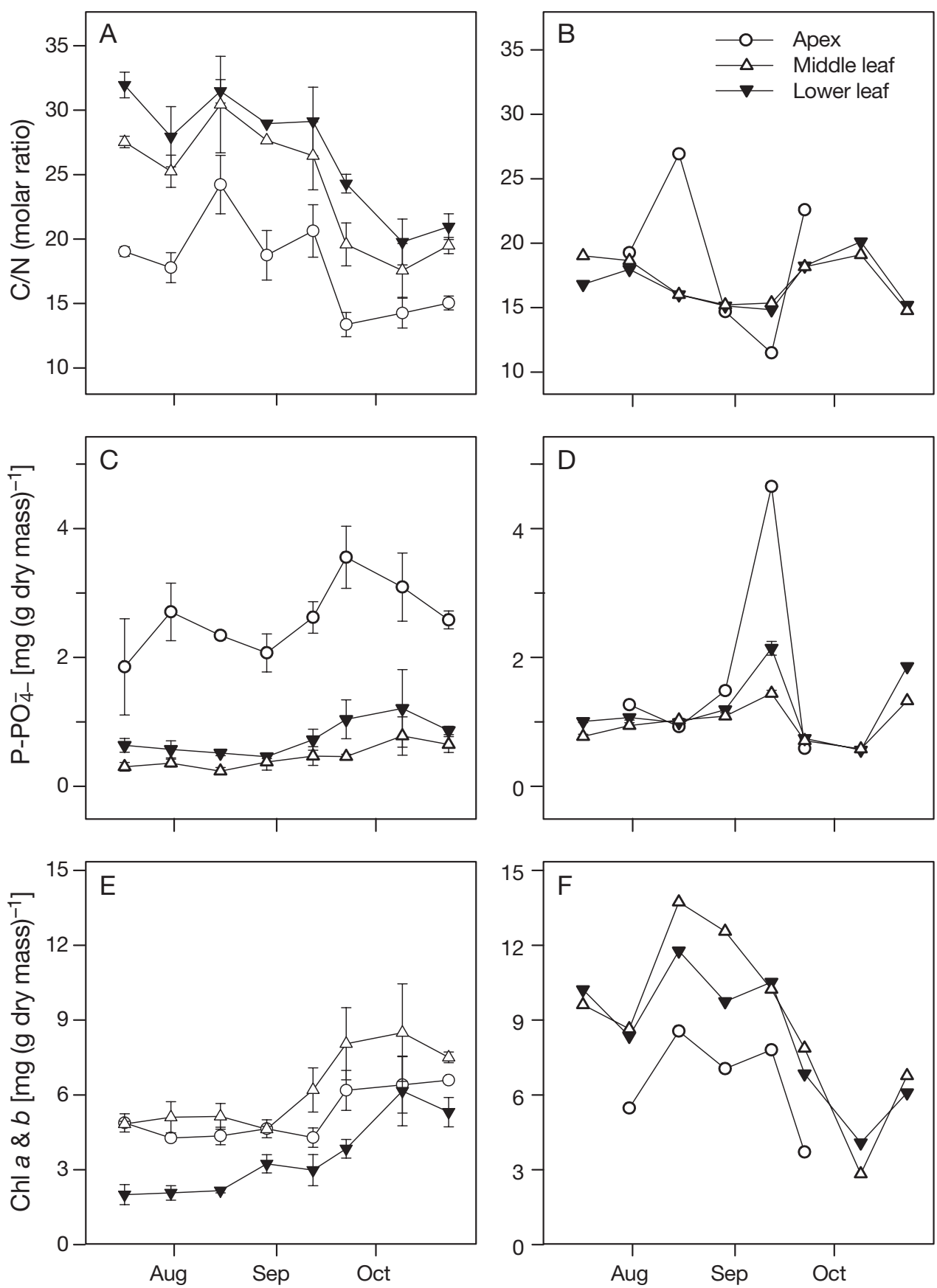

Fig. 1. Myriophyllum spicatum and Potamogeton perfoliatus. Chemical parameters of $M$. spicatum $(\mathrm{A}, \mathrm{C}, \mathrm{E})$ and $P$. perfoliatus $(\mathrm{B}, \mathrm{D}, \mathrm{F})$. $(\mathrm{A}, \mathrm{B})$ $\mathrm{C} / \mathrm{N}$ ratio; $(\mathrm{C}, \mathrm{D})$ phosphorus content; (E,F) chl $a$ and $b$ content. $\mathrm{n}=3$, mean $\pm \mathrm{SD}$

Phenolic compounds

Myriophyllum spicatum had the highest total phenolic content in apices (200 to $250 \mathrm{mg}$ [g dry mass] ${ }^{-1}$ ), followed by middle and lower leaves (67 to 138 and 50 to $70 \mathrm{mg}$ [g dry mass] ${ }^{-1}$, respectively; Fig. 2A). The total phenolic content in Potamogeton perfoliatus was much lower $\left.(21 \pm 9 \mathrm{mg} \text { [g dry mass }]^{-1}\right)$, and it did not differ between apices and leaves (Fig. 2B).

The anthocyanin content in Myriophyllum spicatum was higher in apices $\left(1.5 \pm 0.5 \mathrm{mg}[\mathrm{g} \text { dry mass }]^{-1}\right)$ than in both leaf sections $\left(0.6 \pm 0.3 \mathrm{mg}[\mathrm{g} \text { dry mass }]^{-1}\right.$; Fig. 2C), while in Potamogeton perfoliatus the anthocyanin contents of all plant parts were similar (average $0.3 \pm 0.07 \mathrm{mg}$ [g dry mass $]^{-1}$ ), and no seasonal variation was observed (Fig. 2D).

The major hydrolyzable polyphenol tellimagrandin II in Myriophyllum spicatum exhibited the highest concentration in apices (30 to $70 \mathrm{mg}$ [g dry mass $]^{-1}$ ) followed by both leaf sections ( 2 to $20 \mathrm{mg}$ [g dry mass] ${ }^{-1}$; Fig. 2E). Tellimagrandin II is not present in Potamogeton perfoliatus. 

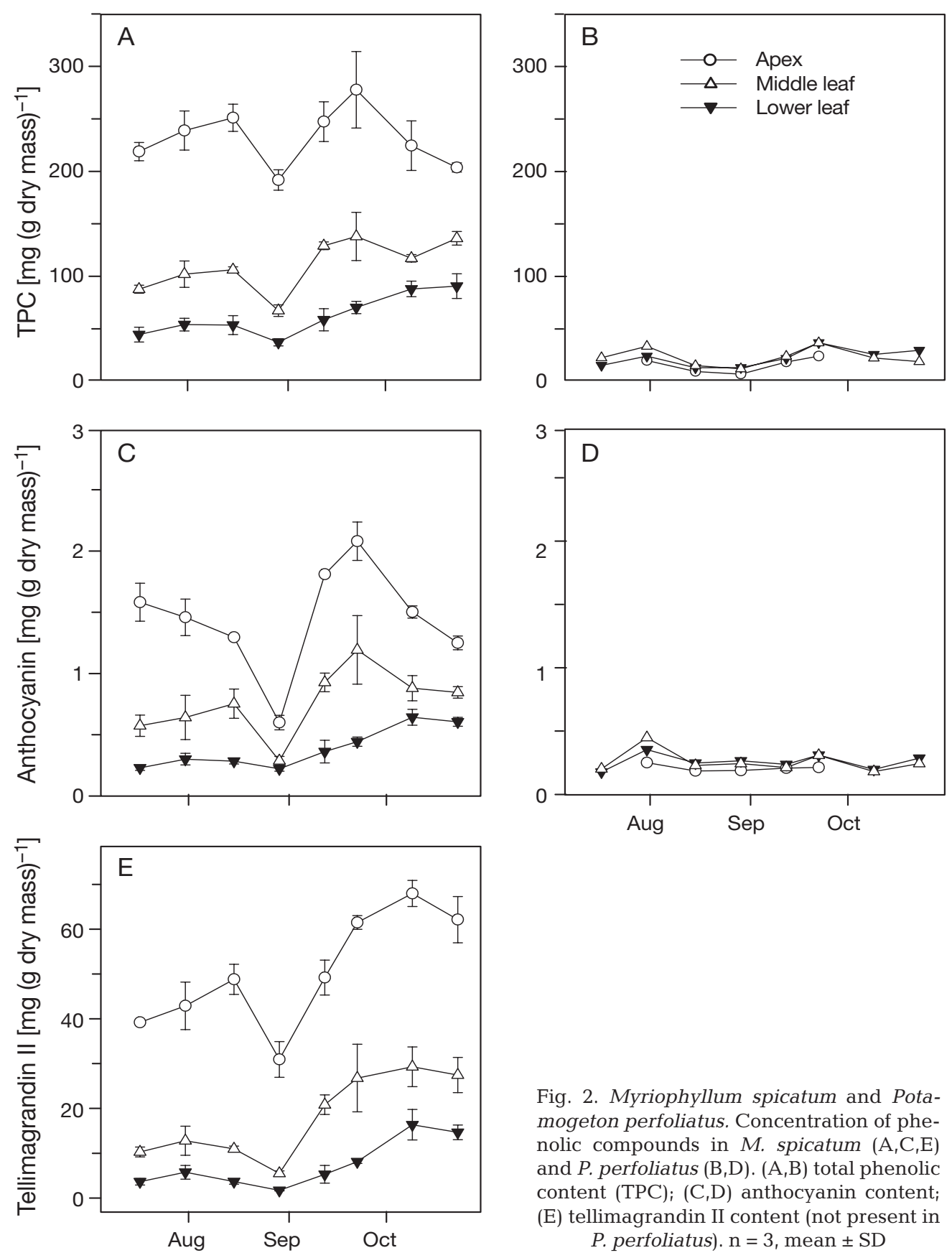

Total bacterial cell counts

We did not observe any significant influence of plant age or sampling time on the total bacterial cell counts on Myriophyllum spicatum (2-way ANOVA, time $\times$ plant part, $F=0.79, \mathrm{p}=0.66$ ). Cell counts on the apices (average cell counts on all sampling dates: $0.63 \pm 0.24 \times$ $10^{6}$ cells $\mathrm{cm}^{-2}$, mean $\pm 1 \mathrm{SEM}$ ) were similar to those on middle leaves $\left(0.66 \pm 0.06 \times 10^{6}\right.$ cells $\left.\mathrm{cm}^{-2}\right)$, and both were slightly lower than those on lower leaves $(1.00 \pm$ $0.11 \times 10^{6}$ cells $\mathrm{cm}^{-2}$ ). Towards autumn, total bacterial

Fig. 2. Myriophyllum spicatum and Potamogeton perfoliatus. Concentration of phenolic compounds in $M$. spicatum $(\mathrm{A}, \mathrm{C}, \mathrm{E})$ and $P$. perfoliatus $(\mathrm{B}, \mathrm{D})$. $(\mathrm{A}, \mathrm{B})$ total phenolic content (TPC); $(\mathrm{C}, \mathrm{D})$ anthocyanin content; (E) tellimagrandin II content (not present in $P$. perfoliatus). $\mathrm{n}=3$, mean $\pm \mathrm{SD}$

cell counts on the lower leaves slightly increased (Fig. 3A). Total bacterial cell counts on the different plant parts of Potamogeton perfoliatus were similar throughout the sampling period (apex: $0.43 \pm 0.12 \times 10^{6}$, middle leaves: $0.20 \pm 0.04 \times 10^{6}$; lower leaves: $0.28 \pm$ $0.05 \times 10^{6}$ cells cm ${ }^{-2}, 2$-way ANOVA, time $\times$ plant part, $F=0.59, \mathrm{p}=0.84 ;$ Fig. 3B). At the end of the sampling period, artificial surfaces had about 13-fold higher bacterial cell counts than at the beginning (from $0.36 \pm$ $0.01 \times 10^{6}$ to $4.79 \pm 1.67 \times 10^{6}$ cells $\mathrm{cm}^{-2}$ ). The bacterial cell counts were higher on the artificial surface $(1.78 \pm$ 

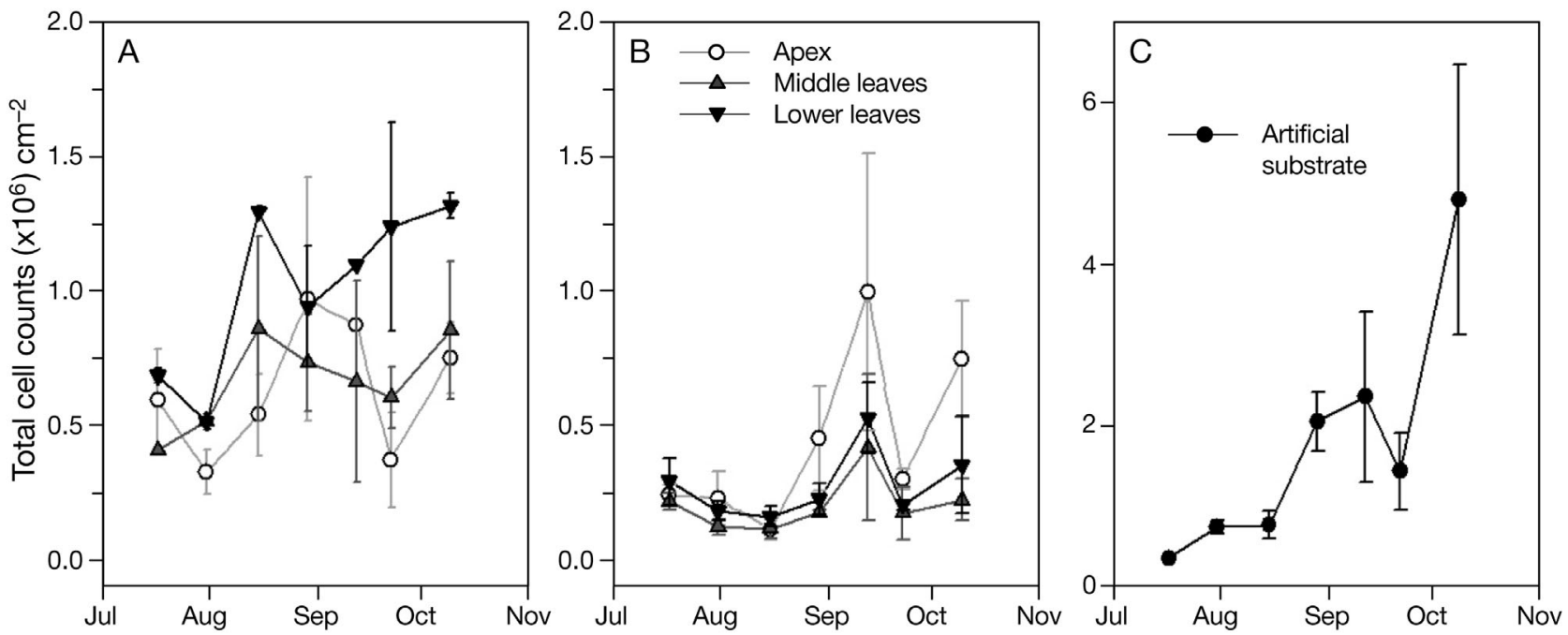

Fig. 3. Myriophyllum spicatum and Potamogeton perfoliatus. Total bacterial cell counts on all substrates during the sampling period. (A) M. spicatum; (B) P. perfoliatus; (C) artificial substrate. Note that the $y$-axis in (C) has a different scale. $\mathrm{n}=3$, mean \pm SEM

$0.57 \times 10^{6}$ cells $\mathrm{cm}^{-2}$ ) than on both macrophytes throughout the sampling period (Fig. 3C). The bacterial cell counts on $P$. perfoliatus were lower on middle and lower leaves than those on middle and lower plant parts on $M$. spicatum (Mann-Whitney rank sum test, middle and lower leaves, both $\mathrm{p}<0.001)$.

\section{Bacterial community composition}

We assessed the bacterial community composition by FISH. The bacterial counts were usually $>50 \%$ of the DAPI counts $(65 \%$ of DAPI counts \pm 16 , mean \pm SD, for all dates and surfaces).

Spatial and temporal variability on different surfaces

The biofilm community composition on Myriophyllum spicatum did not differ much between sampling dates or plant parts (Fig. 4A, C,E). Members of the CFB group and Betaproteobacteria often were the most abundant bacterial groups on the macrophytes and ranged between 0 and $75 \%$ and 3 and $58 \%$ of the DAPI counts, respectively. In a few cases, no $C F B$ bacteria were detected, which may have been caused by the low hybridization efficiency of $<50 \%$ of this probe (see Fig. 4).

The apices of Myriophyllum spicatum had the highest percentage of $C F B$ bacteria (32 $\pm 17 \%$ of DAPI counts, mean $\pm \mathrm{SD})$, followed by the middle $(16 \pm 12 \%$ of DAPI counts) and lower leaves (15 $\pm 10 \%$ of DAPI counts), but with no statistical significance (1-way ANOVA, $p=0.763)$. The percentage of Alphaproteobacteria increased on the apices from late summer to autumn (from 2 to $43 \%$ of DAPI counts, Pearson cor- relation $\mathrm{p}<0.01$ ), stayed more or less constant on middle leaves $(18 \pm 7 \%$ of DAPI counts, Pearson correlation $\mathrm{p}=0.761$ ), and decreased on the lower leaves (from 46 to $10 \%$ of DAPI counts, Pearson correlation $\mathrm{p}=0.0155)$. Planctomycetes and Actinomycetes together accounted for $13 \%$ of the DAPI counts.

On Potamogeton perfoliatus, the differences in biofilm community composition between different plant parts were even less pronounced (Fig. 4B,D,F). The percentage of Betaproteobacteria on the leaves doubled from July (13 $\pm 9 \%$ of DAPI counts) to September (52 $\pm 5 \%$ of DAPI counts: 1-way ANOVA, df $=6, F=$ $6.25, \mathrm{p}<0.001$, Holm-Sidak post hoc test $\mathrm{p}<0.005$ for comparisons between July and September). Members of the $C F B$ group made up the largest portion of all detected bacteria on all $P$. perfoliatus plant parts (10 to $50 \%$ of DAPI counts, Fig. 4B, D, F). In general, the percentage of $C F B$ bacteria on all plant parts declined towards autumn, with an intermediate peak in midAugust (54 $\pm 21 \%$ of DAPI counts), but this development was not significant (Pearson correlation $\mathrm{p}=0.77$ ). The percentage of Alphaproteobacteria ranged from 8 to $27 \%$ of DAPI counts on all plant parts, and there was no seasonal trend (1-way ANOVA, $F=2.66$, p > 0.01).

The biofilm on artificial surfaces was dominated by $\mathrm{Al}$ phaproteobacteria ( $23 \pm 10 \%$ of DAPI counts), members of the CFB group $(16 \pm 10 \%$ of DAPI counts), and Betaproteobacteria ( $8 \%$ of DAPI counts, Fig. 4G). Gammaproteobacteria, Planctomycetes, and Actinomycetes together accounted for up to $10 \%$ of the biofilm community. There was no seasonal trend for any bacterial group on this surface (Pearson correlation: Alphaproteobacteria $\mathrm{p}=0.037$, Betaproteobacteria $\mathrm{p}=0.66$, Gammaproteobacteria $\mathrm{p}=0.22$, Planctomycetes $\mathrm{p}=$ 0.331, Actinomycetes $\mathrm{p}=0.58, C F B$ group $\mathrm{p}=0.953)$. 

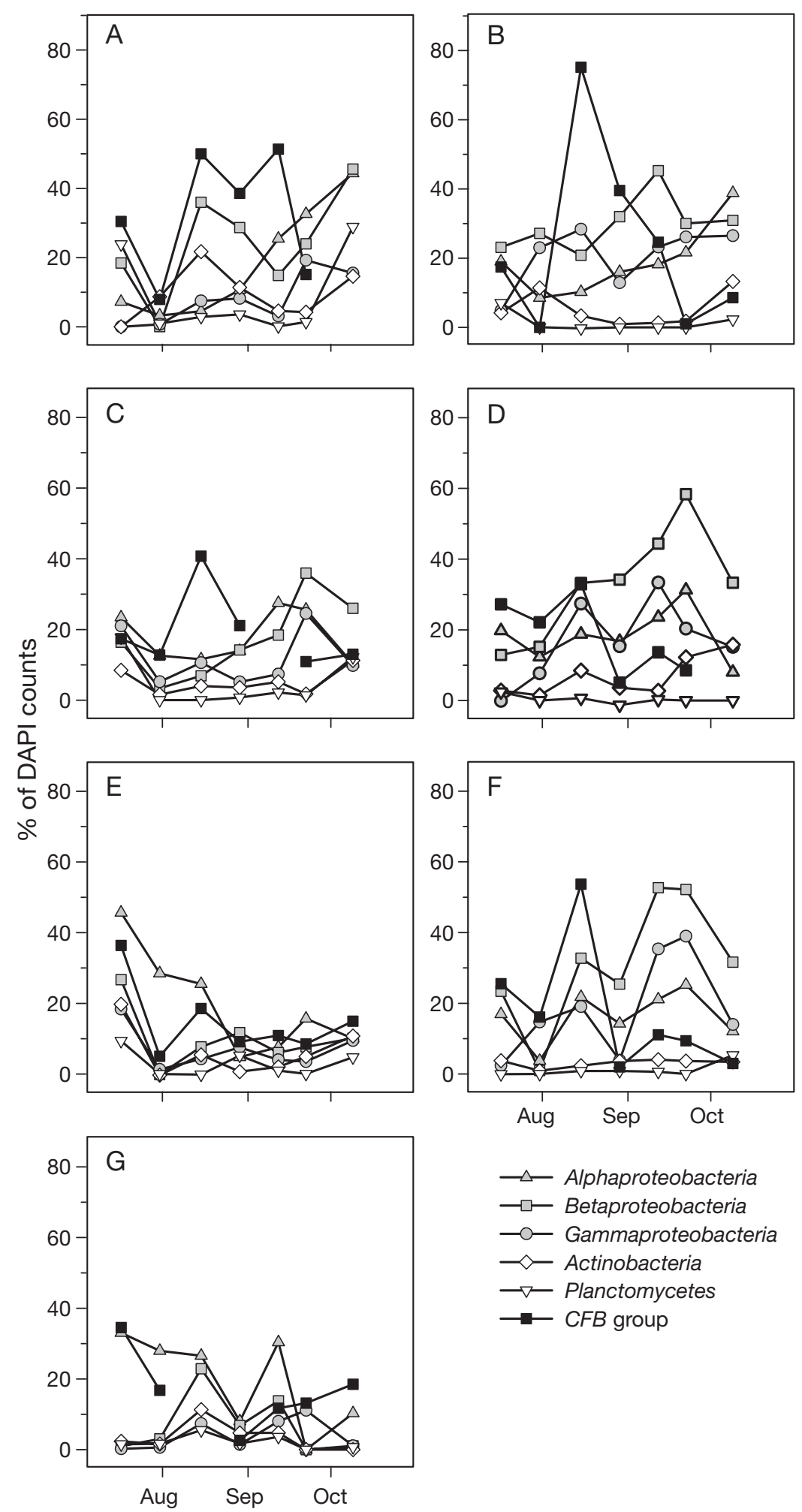

Fig. 4. Myriophyllum spicatum and Potamogeton perfoliatus. Biofilm community composition on $M$. spicatum, P. perfoliatus, and artificial substrates. (A) $M$. spicatum apex; (B) P. perfoliatus apex; (C) M. spicatum middle leaf; (D) $P$. perfoliatus middle leaf; (E) M. spicatum lower leaf; (F) $P$. perfoliatus lower leaf; (G) artificial substrate. $\mathrm{n}=3$. SD ranged between 7 and $135 \%$ but has not been displayed for clarity
Comparison between surfaces

The biofilm on Potamogeton perfoliatus had a much higher percentage of Betaproteobacteria than that on Myriophyllum spicatum and artificial surfaces $(17 \pm 8 \%$ of DAPI counts for M. spicatum, $31 \pm 12 \%$ for $P$. perfoliatus, and $7 \pm 8 \%$ for artificial surfaces; 1-way ANOVA, Holm-Sidak post hoc test $\mathrm{p}<0.0001$ for both comparisons).

The percentage of Gammaproteobacteria on Potamogeton perfoliatus was higher than on Myriophyllum spicatum on every plant part $(19 \pm 10 \%$ and $9 \pm 4 \%$ of DAPI counts, respectively; Mann-Whitney rank sum test $\mathrm{p}<0.001$ ). The biofilm on the artificial surfaces contained Gammaproteobacteria on all sampling dates, but the percentages varied ( 1 to $11 \%$ of DAPI counts). The percentage of $C F B$ bacteria and Alphaproteobacteria on the 2 plant species did not differ, irrespective of the plant part, and were also similar to that found on artificial surfaces (16 to $20 \%$ of DAPI counts; Alphaproteobacteria: $t$-test $\mathrm{p}=0.56$; CFB: Mann-Whitney rank sum test $\mathrm{p}=0.41$ ). The percentage of Actinomycetes was low, but they were always present on all surfaces, ranging between 1 and $22 \%$ of DAPI counts (surface: 1-way ANOVA on ranks, post hoc Dunn's method, $F=8.34, \mathrm{p}=0.015$; plant age: 1-way ANOVA on ranks, post hoc Dunn's method, $F=0.98, \mathrm{p}=0.612$ ). The percentage of Planctomycetes on $M$. spicatum apices was as high as $29 \%$ of DAPI counts, but Planctomycetes were also lacking in some samples. Planctomycetes were mostly absent on $P$. perfoliatus throughout the sampling period; low but constant percentages were found on the artificial surfaces.

Effect of plant chemical composition and environmental factors on the biofilm community composition

We performed a BEST-ENV analysis to elucidate the major factors influencing the biofilm community composition. The analysis indicated that of all plant chemical composition parameters measured, only the carbon and total phenolic contents marginally explained the variation in the commu- 


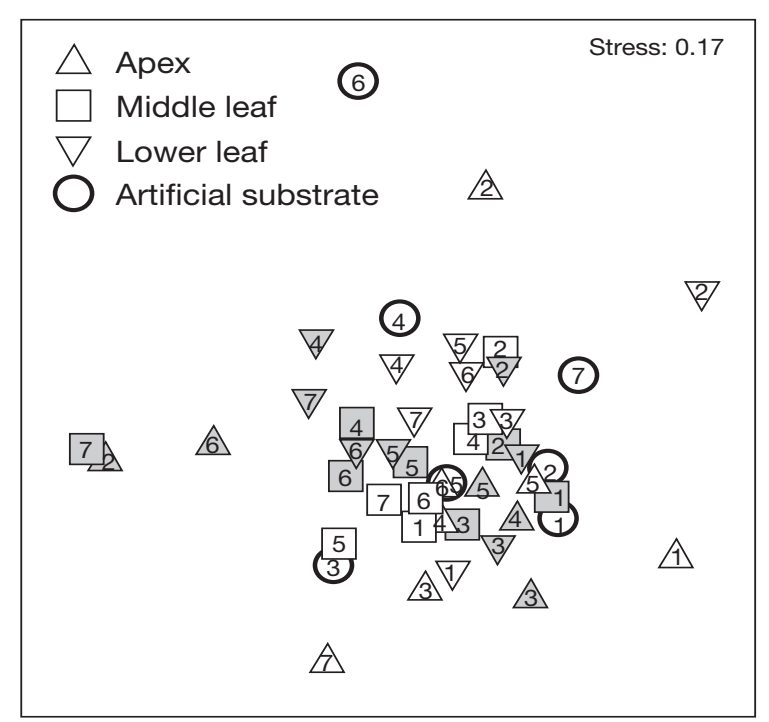

Fig. 5. Myriophyllum spicatum and Potamogeton perfoliatus. NMDS plot of FISH abundance data based on a Bray-Curtis dissimilarity matrix. Open symbols: $M$. spicatum; filled symbols: P. perfoliatus. Sampling date numbers are listed in Table 2

nity compositions on the biofilms of the 2 plant species ( $\rho=0.175, p=0.1, n=42$ ). The environmental factors water level and conductivity explained most of the variability $(\rho=0.33, p=0.002, n=42)$. When both plant chemical composition and environmental variables were considered, the major predictors were carbon content, total phenolic content, water temperature, water level, conductivity, and $\mathrm{pH}$, and the correlation coefficient increased ( $\rho=0.354, p=0.009$ ). To compare the biofilm community composition on the artificial surfaces to those on the plants, we carried out the BEST-ENV analysis only with environmental variables. Here, conductivity explained most of the variability in the biofilm community composition ( $\rho=0.217, \mathrm{p}=0.002, \mathrm{n}=49$ ).

Despite these differences, the overall biofilm community composition did not differ much depending on surface, plant part, or season, as indicated by NMDS analysis (Fig. 5). Slight changes occurred with season, especially at the beginning of the sampling period.

\section{Denaturing gradient gel electrophoresis}

Biofilm community composition on apices and leaves of Myriophyllum spicatum (summer 2005)

The DGGE banding pattern on apices and leaves of Myriophyllum spicatum differed slightly on all sampling dates (Figs. 6 \& S1, available as Supplementary Material at www.int-res.com/articles/suppl/ a058p079_app.pdf). NMDS showed a stronger separation in July and October than in August. In both July and October, however, some replicates diverged. Based on ANOSIM, the biofilm community composition on apices and leaves showed a slight but significant separation in July and October $(\mathrm{R}=0.356$ and $0.333, \mathrm{p}=$ 0.003 and 0.005 , respectively), while differences in August were not significant $(R=0.165, p=0.092)$.

Biofilm community composition on different surfaces

In summer 2006, DGGE banding patterns revealed that the bacterial biofilm on Myriophyllum spicatum apices differed from that on Potamogeton perfoliatus apices and the artificial surface (Fig. 7A). Most of the $P$. perfoliatus apex and artificial surface samples clustered together, whereas apex samples of $M$. spicatum formed a distinct cluster, except the sample from the end of August. The biofilm community compositions on the leaves of both macrophytes and the artificial surfaces were similar (Fig. 7B), and we observed no succession in the community composition on apices, leaves, or artificial surfaces. The 2 macrophytes did not differ significantly when the biofilm community composition of apices (Fig. 7C) and leaves (Fig. 7D) were compared (ANOSIM based on NMDS plots; $\mathrm{R}=0.105$ and $-0.227, \mathrm{p}=0.021$ and 0.99 , respectively.)

\section{Sequencing of single DGGE bands}

DGGE bands excised from the gels were re-amplified and sequenced. We analyzed 14 bands of the apices (Fig. S2A available as Supplementary Material at www.int-res.com/articles/suppl/a058p079_app.pdf) with BLAST (Altschul et al. 1990). Most of the retrieved sequences belonged to Betaproteobacteria (50\%) and Gammaproteobacteria (21\%), and the rest (29\%) could only be assigned to the domain Bacteria (Table 3 ). The closest relatives based on a BLAST search were from soil or freshwater habitats, and the sequences were mostly unpublished. We analyzed 16 bands of the leaves; $4 \%$ belonged to the Gammaproteobacteria, $6 \%$ each to the Actinobacteria, Betaproteobacteria, cyanobacteria, and chloroplasts, and the remainder (50\%) could only be assigned to the domain Bacteria (Table 3, Fig. S2B). These sequences were similar mostly to those from other freshwater studies (Besemer et al. 2007, Edlund \& Jansson 2008).

Effect of plant chemical composition and environmental factors on the biofilm community composition

We performed a separate BEST-ENV analysis for leaves and apices of both plants to elucidate the major 
Fig. 6. Myriophyllum spicatum. Cluster analysis of DGGE banding patterns of samples in 2005. $(\mathrm{A}, \mathrm{D})$ July; (B,E) August; $(\mathrm{C}, \mathrm{F})$ October. (A-C) determined by UPGMA; (D-F) NMDS plots. Open circles: apices; filled inverted triangle: leaves
A

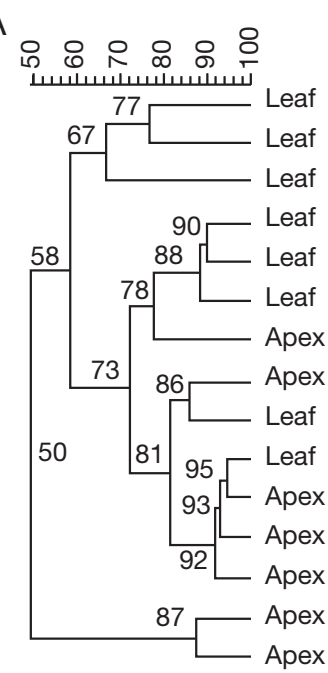

D

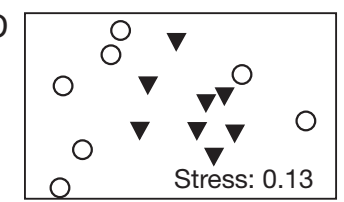

B

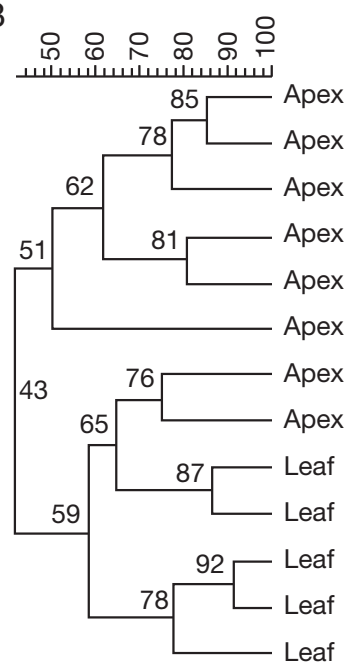

E

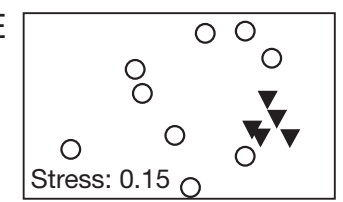

C

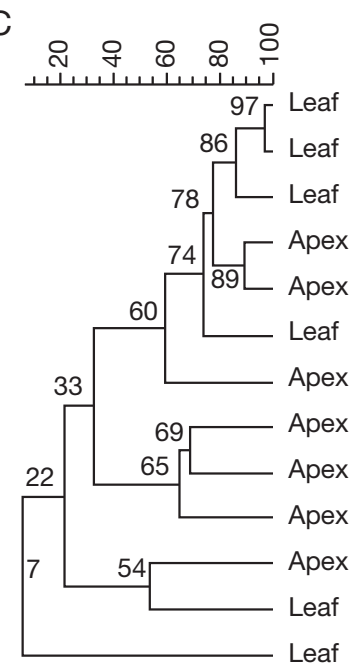

F

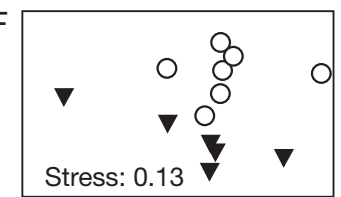

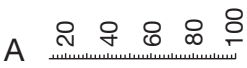

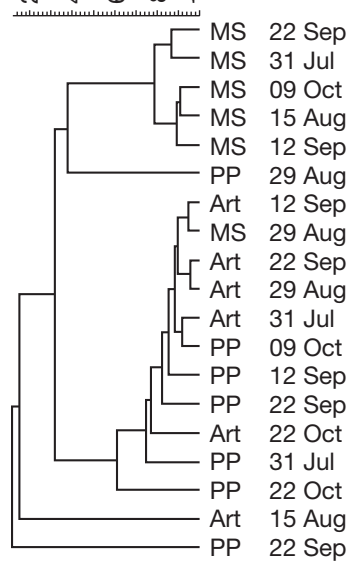

C

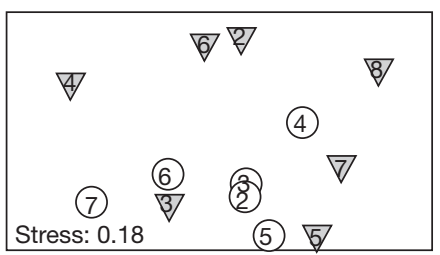

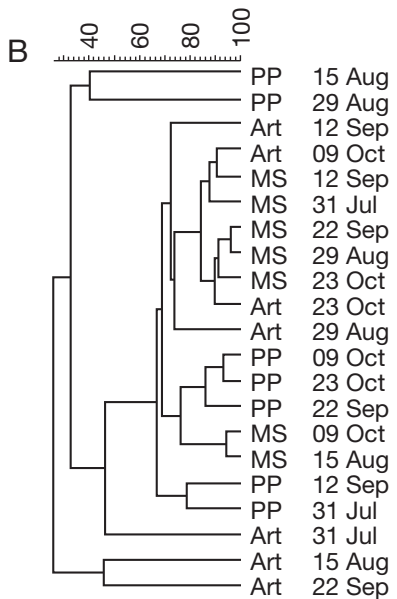

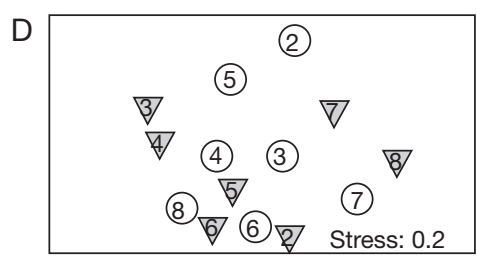

Fig. 7. Myriophyllum spicatum and Potamogeton perfoliatus. Cluster analysis of DGGE banding patterns of the heterotrophic biofilm community on $M$. spicatum (MS), P. perfoliatus (PP), and artificial substrates (Art) in 2006. (A) Apices of both plant species compared to artificial substrates; (B) lower leaves of both plant species compared to artificial substrate. (C, D) NMDS analysis of DGGE banding patterns of $M$. spicatum (open circles) and P. perfoliatus (filled inverted triangles) in 2006; (C) apex; (D) leaves. Numbers given indicate the sampling date (see Table 2)

factors influencing the biofilm community composition as determined by DGGE. The highest correlation coefficient $(\rho)$ was achieved for the carbon and phosphorus contents of the apices, which did not result in significant effects owing to the low replicate numbers $(\rho=0.249$, p > $0.16, \mathrm{n}=13$ ). The same was true for the environmental factors water level and conductivity ( $\rho=0.140, p=0.27, n=13$ ).

We performed the same analyses for the leaf sections. The plant chemical composition did not explain the variability of our samples ( $\rho=0.076, p=0.95)$. Of all environmental factors, conductivity explained most of the variability ( $\rho=0.383, p=0.026$ ). This correlation was not improved when all environmental factors were combined with plant chlorophyll content $(\rho=0.378 ; p=0.059)$.

\section{DISCUSSION}

\section{Total bacterial cell counts}

Submerged macrophytes greatly increase the attachment area for organisms in littoral habitats (Jeppesen et al. 1998). The relationship between plant surface and biomass varies substantially, both intra- and interspecifically (Sher-Kaul et al. 1995). We therefore precisely 
Table 3. Myriophyllum spicatum and Potamogeton perfoliatus. Results of BLAST analysis of 16S rRNA gene sequences obtained from excised DGGE bands from the biofilm of the substrate. Numbers in the first column indicate the bands excised from the gels shown in Fig. S2A (apices) and S2B (leaves) (available as Supplementary Material at www.int-res.com/articles/suppl/a058p079_app.pdf); accession numbers are given in parentheses. Identical source names represent identical studies

\begin{tabular}{|c|c|c|c|}
\hline Substrate & Most similar to (\% identity) & \multicolumn{2}{|c|}{ Accession no. $\quad$ Source } \\
\hline \multicolumn{4}{|c|}{ Myriophyllum spicatum apex } \\
\hline & Betaproteobacteria & & \\
\hline 20 (FJ652085) & Uncultured Ideonella sp. clone GASP-MA2S1_A04 (98) & EF662829 & Bacterial soil communities in Michigan \\
\hline 4 (FJ652077) & Uncultured betaproteobacterium clone CH_02 (97) & EF562573 & Complex organic matter degradation \\
\hline $12($ FJ652084) & Uncultured Ideonella sp. clone GASP-MA2S1_A04 (97) & EF662829 & Bacterial soil communities in Michigan \\
\hline \multirow[t]{2}{*}{5 (FJ652081) } & Uncultured Rubrivivax sp. clone GASP-WDOW1_D03 (97) & EF075729 & Soil in pasture and cropping systems \\
\hline & Other bacteria & & \\
\hline 18 (FJ652082) & Uncultured bacterium clone $164 \mathrm{ds} 20$ (100) & AY212616 & Equine fecal contamination \\
\hline 8 (FJ652079) & Uncultured bacterium clone $164 \mathrm{ds} 20$ (93) & AY212616 & Equine fecal contamination \\
\hline \multicolumn{4}{|c|}{ M. spicatum leaves } \\
\hline & Other bacteria & & \\
\hline 6 (FJ652089) & Uncultured bacterium clone YCC126 (95) & EF205477 & Geothermal regions in central Tibet \\
\hline 12 (FJ652098) & Uncultured bacterium clone M1-53 (96) & EU015116 & Estrogen-degrading membrane bioreactors \\
\hline \multirow[t]{2}{*}{23 (FJ652086) } & Uncultured bacterium clone YCC126 (95) & EF205477 & Geothermal regions in central Tibet \\
\hline & Betaproteobacteria & & \\
\hline \multirow[t]{2}{*}{13 (FJ652097) } & Hydrogenophaga taeniospiralis clone SE57 (94) & AY771764 & Arctic \\
\hline & Actinomycetes & & \\
\hline \multirow[t]{2}{*}{7 (FJ652101) } & Uncultured actinobacterium clone IRD18A09 (96) & AY947900 & River bacterioplankton \\
\hline & Cyanobacteria & & \\
\hline 21 (FJ652087) & Uncultured cyanobacterium clone RD107 (96) & & \\
\hline \multicolumn{4}{|c|}{ Potamogeton perfoliatus apex } \\
\hline & Betaproteobacteria & & \\
\hline 19 (FJ652080) & Uncultured Burkholderiales clone Hv(lab)_2.15 (99) & EF667915 & Basal metazoan Hydra \\
\hline \multirow[t]{2}{*}{16 (FJ652073) } & Methylophilus sp. U33 (98) & EU375653 & Organic pollutants degradation \\
\hline & Gammaproteobacteria & & \\
\hline 10 (FJ652078) & Clonothrix fusca strain AW-b (93) & DQ984190 & Clonothrix fusca Roze, 1896 \\
\hline 1 (FJ652076) & Methylomonas methanica clone VAS23 (72) & AM489704 & Baltic Sea sediments \\
\hline & Other bacteria & & \\
\hline 11 (FJ652075) & Uncultured bacterium clone MA34_2003DFa_B05 (90) & EF378328 & Agricultural soil community \\
\hline \multicolumn{4}{|c|}{ P. perfoliatus leaves } \\
\hline & Gammaproteobacteria & & \\
\hline 3 (FJ652091) & Clonothrix fusca strain AW-b (93) & DQ984190 & Clonothrix fusca Roze, 1896 \\
\hline 4 (FJ652093) & Clonothrix fusca strain AW-b (92) & DQ984190 & Clonothrix fusca Roze, 1896 \\
\hline 9 (FJ652090) & Acinetobacter sp. Hg4-05 16S (99) & EU372903 & China sea \\
\hline \multirow[t]{2}{*}{17 (FJ652092) } & Clonothrix fusca strain AW-b (93) & DQ984190 & Clonothrix fusca Roze, 1896 \\
\hline & Other bacteria & & \\
\hline 20 (FJ652095) & Uncultured bacterium clone cams48-2 (95) & AY544224 & Lake Constance $M$. spicatum \\
\hline 15 (FJ652096) & Uncultured bacterium clone cams48-2 (95) & AY544224 & Lake Constance $M$. spicatum \\
\hline 26 (FJ652100) & Uncultured bacterium clone M1-53 (88) & EU015116 & Estrogen-degrading membrane bioreactors \\
\hline \multirow[t]{2}{*}{27 (FJ652099) } & Uncultured bacterium isolate DGGE gel band out_1 (84) & EF396239 & Stream biofilm \\
\hline & Chloroplasts & & \\
\hline 2 (FJ652088) & Calycanthus floridus chloroplast (94) & DQ629462 & Calycanthus \\
\hline \multicolumn{4}{|c|}{ Artificial substrate } \\
\hline & Betaproteobacteria & & \\
\hline 15 (FJ652074) & Ralstonia sp. JB1B3 (100) & EU375662 & Organic pollutant degradation \\
\hline 8 (FJ652094) & Ralstonia sp. JB1B3 (99) & EU375662 & Organic pollutant degradation \\
\hline & Other bacteria & & \\
\hline 3 (FJ652083) & Uncultured bacterium isolate DGGE gel band D2/3_1 (98) & EF208596 & Daggyai Tso geothermal field of Tibet \\
\hline
\end{tabular}


measured by image analysis each leaf analyzed for bacterial biofilm composition. Younger and older leaves have distinct surface-to-biomass ratios that differ by a factor of 2, especially in Myriophyllum spicatum (Hempel et al. 2008).

Total bacterial cell counts were highest on the artificial surfaces, probably caused by the high settlement of Dreissena polymorpha and the related deposition of pseudofeces (Stewart et al. 1998) after 1 mo of exposure. The counts increased on all surfaces towards autumn. On the plants, this increase might be a consequence of leaching from senescing plants (Huss Wehr 2004, Farjalla et al. 2009).

Bacterial densities on the macrophytes in 2006 were constant and similar to those in $2005\left(1.3-1.7 \times 10^{6}\right.$ cells $\mathrm{cm}^{-2}$; M. Hempel unpubl. data), but compared to similar studies (Hossell \& Baker 1979, Hong et al. 1999, Olapade \& Leff 2006), the bacterial cell numbers on plants and artificial surfaces in the present study were low. The higher bacterial cell numbers on Myriophyllum spicatum than on Potamogeton perfoliatus in our study might be accounted for by the higher surfaceto-volume ratio and the whorl-like structure of $M$. spicatum leaves, which promotes the settling of algal epiphytes (Lalonde \& Downing 1991). M. spicatum releases allelochemically active polyphenols and other organic compounds (Gross et al. 1996, Gross 2003), and tellimagrandin II is easily degraded to a sugar moiety and gallic acid, which are good substrates for some microorganisms (Müller et al. 2007). Whether antibacterial compounds found in P. perfoliatus (Bushmann \& Ailstock 2006) affect bacteria at ecologically relevant concentrations remains open.

\section{Bacterial community composition}

With DGGE and to some extent FISH, we found a distinct bacterial community composition on Myriophyllum spicatum apices that differed from that on leaves in 2005, and differed from that on Potamogeton perfoliatus and on the artificial surfaces in 2006.

We selected probes for different bacterial groups based on results of related field studies (Brümmer et al. 2000, Schweitzer et al. 2001). In most of our samples, the sum of bacterial cells detected by all probes accounted for $>100 \%$ of those detected by the EUB probe. For better detection of bacteria, other authors have used a mixture of different EUB probes (EUB I-III), which also detect Planctomycetes (Daims et al. 1999). Since the numbers of Planctomycetes in the present study were very low, it is unlikely that the use of the EUB I-III mixture would have resulted in higher EUB counts. We also used a probe for Archaea (Arch915) on Myriophyllum spicatum leaves, but only found a few scattered signals.
The CFB group was the most dominant bacterial group on all surfaces, and these results were obtained even though the $C F B$ probe used might be of low quality (Loy et al. 2003). This group is frequently found on biofilms in high abundance. The high abundance of members of the $C F B$ group on our surfaces might be due to the presence of complex organic compounds, such as allelochemicals released by the plants or compounds recycled within the biofilm. Members of the CFB group, and also Betaproteobacteria, are believed to degrade high-molecular-weight dissolved organic matter (Kirchman 2002). Irrespective of any methodological restrictions, our FISH data indicated that differences in biofilm community composition were mainly due to differences in the percentages of Beta-, Alpha-, and Gammaproteobacteria. The high numbers of Gammaproteobacteria found on Potamogeton perfoliatus in autumn might be explained by a higher nutrient availability at the end of the vegetation period, when plants are more senescent and nutrient leakage is enhanced. Myriophyllum spicatum does not decline so early during the vegetation period, and the nutrient leakage in autumn is therefore probably lower than in $P$. perfoliatus, as indicated by the increased nitrogen and phosphorus contents of M. spicatum in autumn (Fig. 1). Overall, the biofilm community composition found on all surfaces in the present study is similar to that found on lake snow particles in Lake Constance (Weiss et al. 1996, Schweitzer et al. 2001).

In general, the biofilm community composition, especially Alphaproteobacteria, displayed a higher spatio-temporal variability on Myriophyllum spicatum than on Potamogeton perfoliatus. The chemical gradients from apices to leaves in $M$. spicatum were also pronounced, especially that of phenolic compounds, nitrogen, and phosphorus, whereas the chemical composition of $P$. perfoliatus did not display such a spatial or temporal heterogeneity (Figs. 1 \& 2). For example, the apices of $M$. spicatum contained higher amounts of anthocyanins than older leaves, as has also been observed for terrestrial plants (Gould 2004). In general, the differences in the content of phenolic compounds between the apices and leaves of $M$. spicatum decreased towards autumn and were most pronounced in summer (Fig. 2C). Freshwater M. spicatum apices also exhibited a distinct community composition when compared to other freshwater and brackish water plants (Hempel et al. 2008), which might also be related to higher phenolic content. The spatial differences in the biofilm community composition were confirmed by DGGE analysis of the same data set, which demonstrated that especially the biofilm community composition of $M$. spicatum apices differed from that on $M$. spicatum leaves, $P$. perfoliatus apices and leaves, 
and artificial surfaces. Betaproteobacteria were more abundant in the biofilm of $P$. perfoliatus, especially in autumn. Betaproteobacteria have been shown to degrade a variety of organic molecules (Cottrell \& Kirchman 2000). The sequences obtained from the DGGE bands showed that Betaproteobacteria, e.g. Ralstonia sp., which are capable of polyphenol degradation, were present (Steinle et al. 1998, Ryan et al. 2007).

Some sequenced DGGE bands from Myriophyllum spicatum and Potamogeton perfoliatus are of special interest. Bands corresponding to 2 Gammaproteobacteria, viz. Acinetobacter sp. and Clonothrix fusca, were found. Acinetobacter sp. forms polyphosphates (Kortstee et al. 1994) and C. fusca is a sheathed methanotroph that often occurs in biofilms of running waters (Vigliotta et al. 2007), which might indicate the presence of methane in the biofilm of the macrophytes. Methane can be transported through the lacunar system from the roots to the leaves in many aquatic plants, and this mechanism supports methane oxidation by epiphytic bacteria (Schuette 1996, Heilman \& Carlton 2001). Other sequences were affiliated with methylotrophic bacteria. Polymer-degrading bacteria and methylotrophs have also been found in a study on macrophytes in fresh, brackish, and marine waters (Crump \& Koch 2008). These results indicate that the biofilm community on $M$. spicatum and $P$. perfoliatus is well adapted to organic compounds, such as polyphenols and/or methane, released by the plant. The majority of 16S rRNA gene sequences in the BLAST database is closely related to the macrophyte biofilm sequences; however, as they belong to yet uncultured strains, they do not allow hypotheses on their ecosystem functions.

Water level and conductivity were the strongest predictors of the biofilm community composition as shown by our BEST-ENV analyses of environmental variables, plant chemical composition, and the biofilm community composition based on FISH data. Tissue carbon and, in contrast to our predictions, total phenolic content of plants did not explain much of the variation, but together with all environmental variables yielded the highest correlation coefficient. When this analysis was carried out with the DGGE data set, the changes in the biofilm community composition on the apices were neither affected by phosphorus and carbon content nor by conductivity. The community composition on the leaves, however, was influenced by conductivity. It is possible that conductivity is more important for biofilm community composition closer to the ground, where frequent sediment resuspension or local water currents and seepage exert a stronger impact on the biofilm community composition. In studies on free-living bacteria, an effect of $\mathrm{pH}$, conductiv- ity, and temperature on the biofilm community composition has also been found (Lindström et al. 2005, Allgaier \& Grossart 2006). Additional factors that might affect the biofilm community composition on macrophytes are leaf structure, surface-to-biomass ratio, grazing, and nutrient availability (Lalonde \& Downing 1991, Jürgens \& Matz 2002). However, we did not find such distinct differences on the leaves of either plant species as on the apices. In accordance with our FISH analyses, we suggest that the community compositions of older biofilms on leaves of different plants species are more similar than are the community compositions of younger biofilms on leaves and on apices of the same plant species.

The DGGE sequences were mainly affiliated to bacterial species originating in various limnetic habitats, which suggested that, like many other freshwater bacteria (Lindström et al. 2005), these species are widely distributed among habitats (lakes, rivers, sewage). However, the relatively high number of sequences affiliated to bacterial species usually associated with agricultural soil indicates that some biofilm bacteria arose from a terrestrial source. At our sampling site near the Island of Reichenau, which is intensively used for agriculture, these bacteria might originate from the run-off of lake water used for irrigation back into the lake.

The present study showed that the bacterial biofilm community on an artificial surface and on 2 common freshwater macrophytes consisted of all major bacterial groups as determined by FISH. Only the abundance of these groups varied depending on time, plant species, and plant age. DGGE analyses revealed slight differences between apices of Myriophyllum spicatum and those of Potamogeton perfoliatus and the artificial surface. In general, the bacterial biofilm community on all surfaces was very similar. Although the environmental conditions were more or less stable (Table 2), they were stronger predictors of the bacterial community composition than the plant chemical composition, which differed significantly between both macrophytes, based on a BEST-ENV analysis. The slight but distinct spatial variance of the biofilm community composition on $M$. spicatum is most likely affected by differences in polyphenol content between the apices and other plant parts. These differences might reflect specific bacterial functions in the biofilm on this allelochemically active submerged macrophyte. Polyphenol-degrading bacteria might contribute only a small portion to the total community but still could be important for interactions within the biofilm and between the plant and other eukaryotes. Therefore, the quantitative and qualitative importance of polyphenol-degrading bacteria on $M$. spicatum is the subject of our ongoing research. 
Acknowledgements. This work was supported by the German Science Foundation with grant CRC454, project A2 to E.M.G. We thank C. Feldbaum and S. Nadj for technical assistance and J. Hesselschwerdt and S. Werner for help with sampling. M. Moertl provided the PRIMER 6 program. S. Hilt suggested suitable artificial substrate material. G. Heine adapted the digital imaging system Makrophyt. The 'Aquatic Microbial Ecology Group' at IGB-Neuglobsow is acknowledged for their help during DGGE analyses.

\section{LITERATURE CITED}

Allgaier M, Grossart HP (2006) Seasonal dynamics and phylogenetic diversity of free-living and particle-associated bacterial communities in four lakes in northeastern Germany. Aquat Microb Ecol 45:115-128

Altschul SF, Gish W, Miller W, Myers EW, Lipman DJ (1990) Basic local alignment search tool. J Mol Biol 215:403-410

- Amann RI, Binder BJ, Olson RJ, Chisholm SW, Devereux R, Stahl DA (1990) Combination of 16S rRNA-targeted oligonucleotide probes with flow cytometry for analyzing mixed microbial populations. Appl Environ Microbiol 56: 1919-1925

Besemer K, Singer G, Limberger R, Chlup AK and others (2007) Biophysical controls on community succession in stream biofilms. Appl Environ Microbiol 73:4966-4974

Box JD (1983) Investigation of the Folin-Ciocalteau phenol reagent for the determination of polyphenolic substances in natural waters. Water Res 17:511-525

Brümmer IH, Fehr W, Wagner-Dobler I (2000) Biofilm community structure in polluted rivers: abundance of dominant phylogenetic groups over a complete annual cycle. Appl Environ Microbiol 66:3078-3082

> Buesing N, Gessner MO (2006) Benthic bacterial and fungal productivity and carbon turnover in a freshwater marsh. Appl Environ Microbiol 72:596-605

Bushmann PJ, Ailstock MS (2006) Antibacterial compounds in estuarine submersed aquatic plants. J Exp Mar Biol Ecol 331:41-50

- Chand T, Harris RF, Andrews JH (1992) Enumeration and characterization of bacterial colonists of a submersed aquatic plant, Eurasian watermilfoil (Myriophyllum spicatum L.). Appl Environ Microbiol 58:3374-3379

Choi C, Bareiss C, Walenciak O, Gross EM (2002) Impact of polyphenols on growth of the aquatic herbivore Acentria ephemerella. J Chem Ecol 28:2245-2256

Cottrell MT, Kirchman DL (2000) Natural assemblages of marine proteobacteria and members of the CytophagaFlavobacter cluster consuming low- and high-molecularweight dissolved organic matter. Appl Environ Microbiol 66:1692-1697

Crump BC, Koch EW (2008) Attached bacterial populations shared by four species of aquatic angiosperms. Appl Environ Microbiol 74:5948-5957

Daims H, Bruhl A, Amann R, Schleifer KH, Wagner M (1999) The domain-specific probe EUB338 is insufficient for the detection of all Bacteria: development and evaluation of a more comprehensive probe set. Syst Appl Microbiol 22: 434-444

- DellaGreca M, Fiorentino A, Isidori M, Monaco P, Temussi F, Zarrelli A (2001) Antialgal furano-diterpenes from Potamogeton natans L. Phytochemistry 58:299-304

Edlund A, Jansson JK (2008) Use of bromodeoxyuridine immunocapture to identify psychrotolerant phenanthrenedegrading bacteria in phenanthrene-enriched polluted Baltic Sea sediments. FEMS Microbiol Ecol 65:513-525

Eriksson PG, Weisner SEB (1999) An experimental study on effects of submersed macrophytes on nitrification and denitrification in ammonium-rich aquatic systems. Limnol Oceanogr 44:1993-1999

Farjalla VF, Marinho CC, Faria BM, Amado AM, Esteves FD, Bozelli RL, Giroldo D (2009) Synergy of fresh and accumulated organic matter to bacterial growth. Microb Ecol 57: 657-666

Gould KS (2004) Nature's Swiss army knife: the diverse protective roles of anthocyanins in leaves. J Biomed Biotechnol 2004:314-320

> Gross EM (2003) Differential response of tellimagrandin II and total bioactive hydrolysable tannins in an aquatic angiosperm to changes in light and nitrogen. Oikos 103: 497-504

Gross EM, Meyer H, Schilling G (1996) Release and ecological impact of algicidal hydrolysable polyphenols in Myriophyllum spicatum. Phytochemistry 41:133-138

Grossart HP, Levold F, Allgaier M, Simon M, Brinkhoff $T$ (2005) Marine diatom species harbour distinct bacterial communities. Environ Microbiol 7:860-873

Heilman MA, Carlton RG (2001) Methane oxidation associated with submersed vascular macrophytes and its impact on plant diffusive methane flux. Biogeochemistry 52: 207-224

Hempel M, Blume M, Blindow I, Gross EM (2008) Epiphytic bacterial community composition on two common submerged macrophytes in brackish water and freshwater. BMC Microbiol 8:58

Hong SH, Lee YO, Kim HW, Ahn TS (1999) Succession and diversity of attached bacteria on cellulose film and leaves of Potamogeton crispus in Lake Moonchon, Korea. Arch Hydrobiol Spec Issues Advanc Limnol 54:273-282

Hossell JC, Baker JH (1979) A note on the enumeration of epiphytic bacteria by microscopic methods with particular reference to two freshwater plants. J Appl Microbiol 46: $87-92$

> Huss AA, Wehr JD (2004) Strong indirect effects of a submersed aquatic macrophyte, Vallisneria americana, on bacterioplankton densities in a mesotrophic lake. Microb Ecol 47:305-315

Jeppesen E, Sondergaard M, Sondergaard M, Christoffersen K (1998) The structuring role of submerged macrophytes in lakes, Vol 131. Springer, New York, NY

Joint I, Callow ME, Callow JA, Clarke KR (2000) The attachment of Enteromorpha zoospores to a bacterial biofilm assemblage. Biofouling 16:151-158

> Jürgens K, Matz C (2002) Predation as a shaping force for the phenotypic and genotypic composition of planktonic bacteria. Antonie Leeuwenhoek 81:413-434

Kirchman DL (2002) The ecology of Cytophaga-Flavobacteria in aquatic environments. FEMS Microbiol Ecol 39:91-100

> Kortstee GJ, Appeldoorn KJ, Bonting CF, van Niel EW, van Veen HW (1994) Biology of polyphosphate-accumulating bacteria involved in enhanced biological phosphorus removal. FEMS Microbiol Rev 15:137-153

Lalonde S, Downing JA (1991) Epiphyton biomass is related to lake trophic status, depth, and macrophyte architecture. Can J Fish Aquat Sci 48:2285-2291

> Lane DJ, Pace B, Olsen GJ, Stahl DA, Sogin ML, Pace NR (1985) Rapid determination of 16s ribosomal RNA sequences for phylogenetic analyses. Proc Natl Acad Sci USA 82:6955-6959

- Leu E, Krieger-Liszkay A, Goussias C, Gross EM (2002) Polyphenolic allelochemicals from the aquatic angiosperm Myriophyllum spicatum inhibit photosystem II. Plant Physiol 130:2011-2018

> Lindström ES, Kamst-Van Agterveld MP, Zwart G (2005) Distribution of typical freshwater bacterial groups is associ- 
ated with $\mathrm{pH}$, temperature, and lake water retention time. Appl Environ Microbiol 71:8201-8206

Loy A, Horn M, Wagner M (2003) probeBase: an online resource for rRNA-targeted oligonucleotide probes. Nucleic Acids Res 31:514-516

Manz W, Amann R, Ludwig W, Wagner M, Schleifer KH (1992) Phylogenetic oligodeoxynucleotide probes for the major subclasses of proteobacteria-problems and solutions. Syst Appl Microbiol 15:593-600

Manz W, Amann R, Ludwig W, Vancanneyt M, Schleifer KH (1996) Application of a suite of 16S rRNA-specific oligonucleotide probes designed to investigate bacteria of the phylum cytophaga-flavobacter-bacteroides in the natural environment. Microbiology 142:1097-1106

Marshall K, Joint I, Callow ME, Callow JA (2006) Effect of marine bacterial isolates on the growth and morphology of axenic plantlets of the green alga Ulva linza. Microb Ecol 52:302-310

Müller N, Hempel M, Philipp B, Gross EM (2007) Degradation of gallic acid and hydrolysable polyphenols is constitutively activated in the freshwater plant-associated bacterium Matsuebactersp. FB25. Aquat Microb Ecol 47:83-90

Murray JR, Hackett WP (1991) Dihydroflavonol reductase activity in relation to differential anthocyanin accumulation in juvenile and mature phase Hedera helix L. Plant Physiol 97:343-351

Muyzer G, Dewaal EC, Uitterlinden AG (1993) Profiling of complex microbial populations by denaturing gradient gel electrophoresis analysis of polymerase chain reactionamplified genes coding for $16 \mathrm{~s}$ ribosomal RNA. Appl Environ Microbiol 59:695-700

Muyzer G, Teske A, Wirsen CO, Jannasch HW (1995) Phylogenetic relationships of Thiomicrospira species and their identification in deep-sea hydrothermal vent samples by denaturing gradient gel electrophoresis of 16S rDNA fragments. Arch Microbiol 164:165-172

Neef A (1997) Anwendung der In-situ-Einzelzell-Identifizierung von Bakterien zur Populationsanalyse in komplexen mikrobiellen Biozönosen. PhD dissertation, Technical University Munich

Neef A, Amann R, Schlesner H, Schleifer KH (1998) Monitoring a widespread bacterial group: in situ detection of Planctomycetes with 16S rRNA-targeted probes. Microbiology 144:3257-3266

Olapade OA, Leff LG (2006) Influence of dissolved organic matter and inorganic nutrients on the biofilm bacterial community on artificial substrates in a northeastern Ohio, USA, stream. Can J Microbiol 52:540-549

Pernthaler J, Glöckner FO, Schönhuber W, Amann R (2001) Fluorescence in situ hybridization (FISH) with rRNA-targeted oligonucleotide probes. In: Paul JH (ed) Methods in microbiology, Vol 30. Academic Press, San Diego, CA, p 207-226

Phillips GL, Eminson D, Moss B (1978) A mechanism to account for macrophyte decline in progressively eutrophicated freshwaters. Aquat Bot 4:103-126

Porra RJ (1990) The assay of chlorophylls $a$ and $b$ converted to

Editorial responsibility: Staffan Kjelleberg,

Sydney, Australia their respective magnesium-rhodochlorin derivatives by extraction from recalcitrant algal cells with aqueous alkaline methanol: prevention of allomerization with reductants. Biochim Biophys Acta 1015:493-502

> Rao D, Webb JS, Kjelleberg S (2006) Microbial colonization and competition on the marine alga Ulva australis. Appl Environ Microbiol 72:5547-5555

Roller C, Wagner M, Amann R, Ludwig W, Schleifer KH (1994) In situ probing of gram-positive bacteria with high DNA $\mathrm{G}+\mathrm{C}$ content using 23S rRNA-targeted oligonucleotides. Microbiology 140:2849-2858

Ryan MP, Pembroke JT, Adley CC (2007) Ralstonia pickettii in environmental biotechnology: potential and applications. J Appl Microbiol 103:754-764

Sand-Jensen K, Søndergaard M (1981) Phytoplankton and epiphyte development and their shading effect on submerged macrophytes in lakes of different nutrient status. Int Rev Gesamten Hydrobiol 66:529-552

Schuette JL (1996) Lacunar pressures in Myriophyllum heterophyllum: manometric measurement and diurnal gas dynamics in field populations. Aquat Bot 54:321-336

- Schweitzer B, Huber I, Amann R, Ludwig W, Simon M (2001) Alpha- and Beta-Proteobacteria control the consumption and release of amino acids on lake snow aggregates. Appl Environ Microbiol 67:632-645

Sher-Kaul S, Oertli B, Castella E, Lachavanne JB (1995) Relationship between biomass and surface area of six submerged aquatic plant species. Aquat Bot 51:147-154

Steinle P, Stucki G, Stettler R, Hanselmann KW (1998) Aerobic mineralization of 2,6-dichlorophenol by Ralstonia sp. strain RK1. Appl Environ Microbiol 64:2566-2571

> Stewart TW, Miner JG, Lowe RL (1998) Quantifying mechanisms for zebra mussel effects on benthic macroinvertebrates: organic matter production and shell-generated habitat. J N Am Benthol Soc 17:81-94

> Underwood GJC (1991) Colonization and invasion of leaves of the aquatic macrophyte Ceratophyllum demersum L by epiphytic bacteria. Microb Ecol 21:267-275

> Vigliotta G, Nutricati E, Carata E, Tredici SM and others (2007) Clonothrix fusca Roze 1896, a filamentous, sheathed, methanotrophic gamma-proteobacterium. Appl Environ Microbiol 73:3556-3565

Walenciak O (2004) Impact of polyphenols from Myriophyllum spicatum on its herbivore Acentria ephemerella and associated microorganisms. PhD dissertation, University of Konstanz

> Walenciak O, Zwisler W, Gross EM (2002) Influence of Myriophyllum spicatum-derived tannins on gut microbiota of its herbivore Acentria ephemerella. J Chem Ecol 28: 2045-2056

Wallner G, Amann R, Beisker W (1993) Optimizing fluorescent in situ hybridization with rRNA-targeted oligonucleotide probes for flow cytometric identification of microorganisms. Cytometry 14:136-143

Weiss P, Schweitzer B, Amann R, Simon M (1996) Identification in situ and dynamics of bacteria on limnetic organic aggregates (lake snow). Appl Environ Microbiol 62:1998-2005

Submitted: May 12, 2008; Accepted: July 10, 2009

Proofs received from author(s): November 25, 2009 